\title{
Pemanfaaatan Keong Mas (Pomacea Canaliculata) Dalam Pakan Terhadap Produksi Telur dan Kualitas Telur Ayam Ras
}

\section{(The Use of Golden Snail (Pomacea Canaliculata) in Feed toward Eggs Production and Eggs Quality of Layer Chicken)}

\author{
Sumiati, Pardi, Tjokorda Suwhendra Binetra \\ Laboratorium Ilmu Nutrisi dan Makanan Ternak Non Ruminansia \\ Jalan Majapahit No.62 Mataram 83125,NTB,Indonesia \\ Telepon (0370) 633603.Fax (0370) 640592 \\ E-mail: sumiatiunram@ic.id
}

Diterima : 26 September 2019/Disetujui : 18 Oktober 2019

\begin{abstract}
ABSTRAK
Penelitian yang bertujun untuk mengetahui pemanfaatan tepung keong mas dalam pakan terhadap produksi telur ayam ras, telah dilaksanakan pada bulan juli tahun 2018 bertempat di Desa Apitaik Kecamatan Pringgabaya Kabupaten Lombok Timur. Materi yang digunakan dalam penelitian ini yaitu 48 ekor ayam ras petelur umur 7 bulan yang dikelompokkan menjadi 4 kelompok perlakuan. Tiap kelompok terdiri dari 4 ulangan dan tiap ulangan terdiri dari 3 ekor ayam. Pakan yang diberikan tersusun dari 50\% jagung kuning, $16 \%$ dedak padi, 34\% konsentrat layer KLKS dan premix mineral (P0), 50\% jagung kuning, 20\% dedak padi, 25\% konsentrat layer KLKS dan premix mineral (PI), 50\% jagung kuning, 24,29\% dedak padi, 15,71\% konsentrat layer KLKS dan premix mineral PII), 50\% jagung kuning, 24,29\% dedak padi, 15,71\% konsentrat layer KLKS dan premix mineral (PIII). Variabel yang diukur adalah produksi telur, berat telur, konsumsi pakan, konversi pakan, kualitas telur meliputi kadar air, protein dan lemak (variable pokok), kandungan nutrisi keong mas (variable penunjang). Data yang diperoleh dianalisis dengan analisis varians atas dasar rancangan acak lengkap dan bila ada perbedaan diantara perlakuan, dilanjutkan dengan uji jarak berganda Duncan. Hasil penelitian menunjukkan bahwa produksi telur, konsumsi pakan, kadar air dan lemak kasar telur ayam ras dalam penelitian ini antara perlakuan P0, PI, PII dan PIII berpengaruh tidak nyata $(\mathrm{P}>0,05)$ dan berpengaruh nyata terhadap bobot telur, konversi pakan dan kandungan protein kasar telur $(\mathrm{P}<0,05)$.
\end{abstract}

Kata kunci: Keong Mas, Ayam Ras Petelur, Produksi Telur

\begin{abstract}
This research aimed to determine the effect of using golden snail (Pomacea canaliculata) in feed toward eggs production and egg quality of layer chiken. This research was conducted in Juli 2018 at Apitaik West Lombok and laboratory of Animal Nutrition, Animal Scince Faculty, Mataram University. Forty eight of layer chicken were divided into 4 treatments; P0 $(0 \%$ Pomacea canaliculata meal $+50 \%$ yellow corn $+16 \%$ rice bran and $36 \%$ KLKS consentrat), PI( $5 \%$ Pomacea canaliculata meal $+50 \%$ yellow corn, $20 \%$ rice bran and $25 \%$ KLKS consentrat), PII (10\% Pomacea canaliculata meal $+50 \%$ yellow corn $+24,29 \%$ rice bran and $15,71 \% \%$ KLKS consentrat) and PIII (15\% Pomacea canaliculata meal $+50 \%$ yellow corn $+28.57 \%$ rise bren and $6.43 \% \%$ KLKS consentrat). Each treatment consisted of 3 replications and each replication consisted of 3 chickens. All treatments were given iso-protein and iso- energy ratio. Parameters observed in this reaserch were eggs production, feed comsumption, feed conversion, eggs weight and eggs quality (crude protein, crude fat and water). Data obtained in this study were analyzed by Analysis of Variance on the basis of a complete randomized design and if the results were significant followed by the Duncan test. The results show that feed consumption, egg producktion, crude fat and water were not significant $(\mathrm{P}>0,05)$ but egg weight, feed convertion, crude protein of eggs was differ significantly $(\mathrm{P}<0,05)$.
\end{abstract}

Keyword: Golden Snail, Eggs Productin, Layer Chicken 


\section{PENDAHULUAN}

Ayam ras petelur merupakan ayam betina dewasa yang dipelihara khusus untuk diambil telurnya dengan jumlah produksi telur antara 250 sampai 280 butir per tahun. Produksi telur yang baik akan diperoleh pada tahun pertama ayam mulai bertelur dengan puncak produksi pada umur 7-8 bulan dan pada tahun-tahun berikutnya cenderung akan terus menurun (Sudarmono, 2003).

Produksi telur berhubungan langsung dengan konversi pakan, semakin tinggi produksi telur semakin kecil konversi pakan (Wahyu, 1996). Rasyaf (1996) menyatakan bahwa tingkat konversi pakan yang berbeda-beda tergantung kadar protein dan energi metabolisme pakan, suhu lingkungan, umur ayam, kondisi kesehatan dan komposisi pakan. Faktor yang mempengaruhi tingkat produktivitas ternak termasuk produksi telur antara lain manajemen pemeliharaan, lokasi kandang, kondisi pasar, umur ternak , kondisi lingkungan, kesehatan ayam, kualitas pakan yang diberikan (Amrullah, 2003; Rahardjo, 2009; Scott, 1984).

Konsumsi pakan dipengaruhi oleh lingkungan, imbangan zat-zat makanan, kualitas ransum, bangsa ternak, kecepatan pertumbuhan, bobot badan, tingkat produksi, palatabilitas ransum dan tingkat energi ransum, umur ternak, kandungan protein dalam ransum, genetik, kepadatan dalam kandang dan penyakit. Surdayani dan Santoso (1995) bahwa pemberian pakan untuk periode bertelur dapat diberikan sesuai dengan umur ayam, yaitu ayam 19-35 minggu membutuhkan ransum dengan protein $19 \%$; energi metabolisme $2.800 \mathrm{kkal} / \mathrm{kg}$; dan kalsium 3,8-4,2\%, untuk ayam umur 53 minggu sampai 76 atau 80 minggu membutuhkan protein $18 \%$; energi metabolisme $2750 \mathrm{kkal} / \mathrm{kg}$; dan kalsium $4,0-4,4 \%$.
Menurut Yuwanta (2010) berat telur akan terus meningkat secara cepat pada 6 minggu pertama setelah bertelur. Kenaikan berat telur ini disebabkan oleh meningkatnya jumlah putih telur sedangkan berat kuning telur relatif stabil. Menurut SNI:3926:2008 klasifikasi standar berat telur meliputi telur besar (diatas $60 \mathrm{~g}$ ), sedang (50-60g), kecil (kurang dari 50g) (Badan Standar Nasional Indonesia, 2008).

Besarnya telur dipengaruhi oleh banyak faktor termasuk sifat genetik, umur ternak, tingkatan dewasa kelamin, umur, obat-obatan, ukuran telur dan kualitas pakan. Sampai saat ini usaha peternakan masih dihadapkan dengan permasalahan pakan yaitu adanya fluktuasi harga pakan sehingga masyarakat peternak cendrung mencari bahan pakan alternatif guna menekan biaya pakan. Bahan pakan alternative yang cukup potensial, baik dari segi kualitas maupun kuantitas antara lain adalah tepung keong mas.

Keong mas (Pomacea canaliculata) selama ini dikenal sebagai hama potensial tanaman padi. Keong mas mempunyai perkembangannya yang cepat, telurnya bergerombol, yang terdiri dari ratusan telur, berwarna merah muda, justru dianggap bermanfaat sebagai pakan ternak alternative (Saleh, 2016). Hal ini disebabkan keong mas memiliki kandungan nutrisi yang cukup tinggi seperti mineral, protein, dan asam lemak tak jenuh.

Pemanfaatan keong mas sebagai pakan ternak telah banyak dikembangkan. Dalam bentuk segar, keong mas digunakan sebagai pakan sumber protein untuk ternak itik, ayam broiler, burung puyuh, budidaya ikan patin, ikan gabus, ikan sidat, udang, kepiting dan lobster air tawar. Pemberian pakan berbasis protein keong mas pada ternak burung puyuh (Coturnix coturnix) tidak menggangu pertumbuhan dan memberikan pertumbuhan yang baik (Sulistiono, 2007). Menurut Subhan (2014) penggunaan keong mas sebanyak $10 \%$ 
dapat menurunkan kandungan kolesterol daging itik. Sedangkan didalam sebuah penelitian yang telah dilakukan oleh Purnamaningsih (2010) penambahan tepung keong mas dalam ransum sebanyak $9 \%$ tidak mempengaruhi kualitas telur itik.

Subhan (2016) menyatakan bahwa keong mas sebagai pakan itik Alabio menghasilkan pengaruh positif terhadap produksi telur, konversi pakan, penurunan kolesterol daging dan telur, susut masak, dan tidak mempengaruhi tingkat daya terima/kesukaan konsumen terhadap produk itik Alabio, baik daging maupun telur. Dengan demikian merupakan suatu hal yang sangat bijak kalau perhatian ditujukan pada keong mas yang ada di Rawa Lebo Sumbawa guna dapat menekan biaya pakan.

\section{MATERI DAN METODE}

\section{Lokasi}

Penelitian ini telah dilaksanakan di Desa Apitaik kecamatan Pringgabaya kabupaten Lombok Timur selama 2 bulan. Analisis kandungan nutrisi telur dilakukan di Laboratorium Ilmu Nutrisi Makanan Ternak Fakultas Peternakan Universitas Mataram.

\section{Materi}

Materi yang digunakan dalam penelitian ini adalah: ayam ras umur 7 bulan sebanyak 48 ekor yang dikelompokkan secara acak menjadi 4 kelompok perlakuan yaitu PO ( $0 \%$ tepung keong emas), PI (5\% tepung keong emas), PII (10\% tepung keong emas dan PIII (15\% tepung keong emas). Masing-masing perlakuan terdiri dari 3 ulangan dan masing-masing ulangan terdiri dari 3 ekor ayam. Pakan/ransum yang tersusun dari tepung jagung kuning, dedak padi, tepung keong emas, konsentrat Layer KLKS.

Alat yang digunakan adalah Kandang individu dilengkapi tempat pakan dan air minum serta lampu penerang sebanyak 48 unit dengan ukuran per unit adalah panjang $16 \mathrm{~cm}$, lebar $40 \mathrm{~cm}$ dan tinggi $40 \mathrm{~cm}$, ember besar tempat mencampur pakan sebanyak 3 buah, timbangan untuk menimbang pakan dan berat telur serta seperangkat alat untuk analisis nutrisi tepung keong emas dan nutrisi telur ayam.

\section{Metode}

Persiapan. Penelitian ini dimulai dari tahap persiapan yaitu pembuatan kandang, pembuatan tepung keong emas, analisis nutrisi tepung keong emas (kadar air, protein kasar, lemak kasar, lemak kasar, serat kasar dan abu) dan pembuatan pakan untuk masing-masing perlakuan. Pakan untuk masing-masing perlakuan tersusun dari 50\% jagung kuning $+0 \%$ tepung keong mas $+16 \%$ dedak padi dan $34 \%$ konsentrat protein KLKS (PO), 50\% jagung kuning+ $5 \%$ tepung keong mas $+20 \%$ dedak padi dan $25 \%$ konsentrat protein KLKS (PI)., 50\% jagung kuning $+10 \%$ tepung keong mas+ $24.29 \%$ dedak padi, $15.71 \%$ konsentrat protein KLKS (PII), 50\% jagung kuning+ $15 \%$ tepung keong mas $+28.57 \%$ dedak padi dan $6.43 \%$ konsentrat protein KLKS (PIII).

Pemberian pakan dan air minum. Pakan yang diberikan pada masing-masing perlakuan mempunyai kandungan nutrisi iso protein dan iso energi dan diberikan dua kali sehari secara adlibitum.

Pengukuran produksi dan berat telur dilakukan selama satu bulan sedangkan kualitas telur dianalisis pada minggu terakhir penelitian. Data yang diperoleh dalam penelitian ini dianalisis dengan analisis Varians atas dasar rancangan acak lengkap dan apabila hasilnya signifikan dilanjutkan dengan uji Duncan.

Variabel yang diukur dalam penelitian ini adalah:

1. Konsumsi pakan, diperoleh dari jumlah pakan yang diberikan dikurangi pakan yang sisa. 
2. Produksi telur, dapat ditentukan dengan menghitung Hen-day Production (HDP)

$$
\text { HDP }=\underline{\text { Jumlah telur }} \times 100 \%
$$

3. Bobot telur

4. Konversi pakan

Konversi pakan merupakan perbandingan antara konsumsi pakan dengan jumlah produksi telur (Rasyaf,1996)
5. Kandungan nutrisi telur meliputi protein kasar, lemak kasar dan air (Metode AOAC, 1990; Harris, 1970)

\section{HASIL DAN PEMBAHASAN}

1. Konsumsi pakan, produksi telur, berat telur dan konversi pakan ayam ras selama penelitian tertera pada Tabel 1 .

Tabel 1. Rataan konsumsi pakan, produksi telur (HDP), berat telur, konversi pakan, ayam ras tiap perlakuan selama penelitian.

\begin{tabular}{ccccc} 
Perlakuan & $\begin{array}{c}\text { Konsumsi pakan } \\
\text { (g/ekor/hari) }\end{array}$ & $\begin{array}{c}\text { HDP } \\
\mathbf{( \% )}\end{array}$ & $\begin{array}{c}\text { Bobot Telur } \\
\text { (g/btr) }\end{array}$ & $\begin{array}{c}\text { Konversi } \\
\text { Pakan }\end{array}$ \\
\hline P0 & $97,05^{\mathrm{a}}$ & $67,00^{\mathrm{a}}$ & $52.07^{\mathrm{b}}$ & $2.78^{\mathrm{a}}$ \\
\hline PI & $98,15^{\mathrm{a}}$ & $77,00^{\mathrm{a}}$ & $59.48^{\mathrm{a}}$ & $2.17^{\mathrm{b}}$ \\
\hline PII & $93,83^{\mathrm{a}}$ & $68,43^{\mathrm{a}}$ & $54.23^{\mathrm{b}}$ & $2.53^{\mathrm{a}}$ \\
\hline PIII & $95,70^{\mathrm{a}}$ & $67,57^{\mathrm{a}}$ & $54.62^{\mathrm{b}}$ & $2.59^{\mathrm{a}}$ \\
\hline
\end{tabular}

Keterangan: Huruf yang sama pada superskrip menunjukkan tidak berbeda nyata $(\mathrm{P} \geq 0,05)$.

\section{Konsumsi Pakan.}

Konsumsi pakan ayam ras petelur pada masing-masing perlakuan dalam penelitian ini seperti pada Tabel 1 di atas rata-rata sebesar 97,05g/ekor/hari (P0), 98,15g/ekor/hari (PI), 93,83g/ekor/hari (PII) dan 95,70 g/ekor/hari (PIII). Nampak bahwa konsumsi pakan dalam penelitian ini tertinggi pada perlakuan yang diberikan pakan dengan level tepung keong mas 5\% atau pada perlakuan PII .Hasil analisis statistik menunjukan bahwa pemanfaatan tepung keong mas dalam pakan terhadap konsumsi pakan ayam ras petelur selama penelitian pada setiap perlakuan baik pada perlakuan $\mathrm{P} 0(0 \%$ keong mas $)$, PI $(5 \%$ keong mas), PII (10\% keong mas), PIII $(15 \%$ keong mas) tidak memberikan pengaruh yang nyata $(\mathrm{P} \geq 0,05)$. Nampak bahwa kualitas dan palatabilitas pakan dari keempat perlakuan relatif sama dimana ransum dari keempat perlakuan dalam penelitian ini mempunyai kandungan zat gizi dalam kisaran jumlah yang dibutuhkan. Di samping kualitas ransum yang relatif sama, juga disebabkan oleh umur ayam yang digunakan dalam penelitian ini sama yaitu 7 bulan. Konsumsi ransum dipengaruhi oleh lingkungan, imbangan nutrisi, kualitas ransum, bangsa ternak, kecepatan pertumbuhan, bobot badan, tingkat produksi, palatabilitas ransum dan tingkat energi ransum. Konsumsi pakan dipengaruhi oleh beberapa faktor antara lain umur ternak, kandungan protein dalam ransum, genetik, kepadatan dalam kandang, penyakit.

\section{Poduksi Telur}

Rata-rata produksi telur (Hen Day Production) tiap perlakuan yang diperoleh selama penelitian seperti tertera pada Tabel 5. yaitu masing-masing sebesar $67,00 \%$ (PO)., 77,00\% (PI)., 68,43\% (PII) dan $67,57 \%$ (PIII). Nampak bahwa produksi telur ayam yang diperoleh tertinggi pada perlakuan PI diikuti perlakuan PII, PIII dan terendah pada perlakuan P0. Rendahnya produksi telur ayam ras dalam penelitian ini kemungkinan mengalami setres akibat gempa, dimana pada saat kejadian gempa tembok lokasi kandang roboh, ayam sempat keluar dari kandang. Dengan kejadian ini berpengaruh terhadap konsumsi pakan yang 
pada akhirnya berdampak terhadap produksi telur.

Hasil rata-rata produksi telur antara perlakuan P0 dengan PI, PII dan PIII secara statistik menunjukkan pengaruh yang tidak nyata $(P \geq 0,05)$. Tidak adanya perbedaan produksi telur pada semua perlakuan disebabkan konsumsi pakan antara keempat perlakuan sama, hal ini dapat menyebabkan daya cerna dari pakan pada keempat perlakuan sama yang berpengaruh pada konsumsi pakan yang pada akhirnya berpengaruh pada produksi telur. Rahardjo (2009) menyatakan faktor yang dapat menyebabkan produksi telur yang turun dan sering terkait satu sama lain yaitu: kualitas telur itu sendiri, mutu bibit, kecukupan nutrisi, kesehatan ayam, kondisi lingkungan, dan tatalaksana pemeliharaan, perkembangan saluran pencernaan dan reproduksi , umur ternak, lama penyinaran dan stress, kurangnya lama penyinaran dan lelah kandang. Selanjutnya dinyatakan bahwa, untuk mencapai produksi telur yang optimal maka harus disertai dengan konsumsi ransum yang cukup.

\section{Berat Telur}

Rata-rata berat telur perekor setiap perlakuan yang diperoleh selama penelitian seperti tertera pada Tabel 5 yaitu masingmasing sebesar 52,07g (P0)., 59,48g (PI)., 54,23g (PII) dan 54,62g (PIII). Nampak bahwa bobot telur ayam yang diperoleh tertinggi pada perlakuan PI diikuti perlakuan PIII, PII dan terendah pada perlakuan P0. Bila dibandingkan dengan berat telur standar menurut SNI (Badan Standar Nasional Indoensia (2008) maka berat telur ayam yang diperoleh dalam penelitian ini termasuk katagori sedang (51$55 \mathrm{~g}$ ) dan besar (56-60g).

Hasil rata-rata bobot telur antara perlakuan P0,PII dan PIII dengan perlakuan PI secara statistik menunjukkan pengaruh yang nyata $(\mathrm{P} \leq 0,05)$. Adanya perbedaan bobot telur antara perlakuan P0,PII dan PIII dengan perlakuan PI seiring dengan konsumsi pakan antara keempat perlakuan yaitu tertinggi pada perlakuan PI yaitu perlakuan dengan level tepung keong mas sebesar 5\% dalam ransum yang berpengaruh terhadap konsumsi protein. Besarnya telur dipengaruhi oleh banyak faktor termasuk sifat genetik, tingkatan dewasa kelamin, umur, obat-obatan dan pakan. Faktor pakan terpenting yang diketahui mempengaruhi besar telur adalah protein dan asam amino yang cukup dalam ransum dan asam linoleat.

\section{Konversi Pakan}

Rata-rata koversi pakan ayam yang diperoleh selama penelitian untuk masingmasing perlakuan adalah adalah 2,78 (P0), 2,17 (PI), 2.53 (PII) dan 2.59 (PIII). Nampak bahwa konversi pakan terbaik diperoleh pada perlakuan yang diberikan pakan dengan level tepung keong mas sebanyak 5\%. Dijelaskan lebih lanjut oleh Rasyaf (1996) menyatakan bahwa tingkat konversi pakan yang berbeda-beda tergantung kadar protein dan energi metabolisme pakan, suhu lingkungan, umur ayam, kondisi kesehatan dan komposisi pakan. Apabila nilai konversi pakan semakin kecil maka konversi pakan baik, berarti ayam petelur dapat menggunakan pakan dengan baik dan dapat menghasilkan produksi telur dengan baik. Hasil analisis statistik menunjukkan bahwa konversi pakan ayam ras petelur dalam penelitian ini adalah memberikan pengaruh yang nyata $(\mathrm{P}$ $\leq 0,05)$. antara perrlakuan PI dengan perlakuan P0, PII dan PIII. Hal ini berarti bahwa tingkat efisiensi pakan antara perlakuan PI ( $0 \%$ keong mas) memberikan nilai ekonomis yang lebih baik dalam memproduksi telur. Adanya perbedaan konversi pakan antara perlakuan disebabkan berat telur yang diperoleh dalam penelitian ini tertinggi pada perlakuan PI ( $0 \%$ keong mas) dan secara statistic juga memberikan berpengaruh yang nyata $(\mathrm{P} \leq 0,05)$.

2. Kualitas telur ayam ras selama penelitian 
meliputi kadar air, protein kasar dan

lemak kasar tertera pada Tabel 2.

Tabel 2. Rataan kadar air, protein kasar dan lemak kasar telur ayam ras selama Penelitian

\begin{tabular}{cccc}
\hline Perlakuan & Kadar air (\%) & Protein kasar (\%) & Lemak kasar (\%) \\
\hline P0 & $76.38^{\mathrm{a}}$ & $10.97^{\mathrm{c}}$ & $7.53^{\mathrm{a}}$ \\
\hline PI & $76.48^{\mathrm{a}}$ & $11.53^{\mathrm{b}}$ & $8.17^{\mathrm{a}}$ \\
\hline PII & $76.59^{\mathrm{a}}$ & $11.68^{\mathrm{b}}$ & $7.74^{\mathrm{a}}$ \\
\hline PIII & $76.96^{\mathrm{a}}$ & $12.17^{\mathrm{a}}$ & $7.94^{\mathrm{a}}$ \\
\hline
\end{tabular}

Keterangan: Huruf yang sama pada superskrip menunjukkan tidak berbeda nyata $(\mathrm{P} \geq 0,05)$.

Kualitas telur dapat dilihat dari kandungan zat gizinya seperti kandungan protein kasar, lemak kasar dan kandungan airnya. Rata - rata kandungan zat gizi telur ayam setiap perlakuan dalam penelitian ini yang diberikan pakan iso protein dan iso energi masing- masing adalah $10.97 \%$ air, $7.53 \%$ lemak kasar, $10.97 \%$ protein kasar (P0)., 76.48\% air, 8.17\% lemak kasar dan $11.53 \%$ protein kasar (PI)., $76.59 \%$ air, $7.74 \%$ lemak kasar, $11.68 \%$ protein kasar (P1I)., 76.96\% air, 7.94\% lemak kasar dan $12.17 \%$ protein kasar (PIII). Dari hasil yang diperoleh nampak bahwa kandungan zat gizi telur ayam terutama kandungan protein telur tertinggi pada perlakuan PIII yaitu perlakuan yang diberikan pakan dengan level tepung keong mas tertinggi yaitu $15 \%$ dan berturut-turut diikuti oleh perlakuan PII ( $10 \%$ tepung keong mas), perlakuan PI ( $5 \%$ tepung keong mas) dan terendah perlakuan P0 (0\% tepung keong mas). Berdasarkan analisis statistik terhadap kandungan, air dan lemak kasar telur pada perlakuan baik perlakuan PO, PI,PII maupun PIII menunjukkan hasil yang tidak berbeda nyata $(P \geq 0,05)$ Hal ini berarti tingkat kekentalan telur yang diperoleh sama dan ini ada korelasinya dengan kandungan lemak telur. Selanjutnya kandungan protein kasar telur yang diperoleh pada perlakuan P0 dengan PI,PII dan PIII memberikan hasil yang berpengaruh nyata $(\mathrm{P} \leq 0,05)$ dan antara perlakuan PI dengan PII tidak memberikan pengaruh yang nyata $(P \geq 0,05)$. Adanya pengaruh yang nyata terhadap kandungan protein telur antara perlakuan P0 dengan PI,PII dan PIII kemungkinan disebabkan perbedaan kualitas pakan terutama kualitas protein pakan antara perlakuan.

\section{SIMPULAN}

Berdasarkan hasil penelitian yang diperoleh dapat disimpulkan :

1. Pemberian keong mas $0 \%, 5 \%, 10$ $\%$ dan $15 \%$ dalam ransum berpengaruh tidak nyata $(\mathrm{P} \geq 0,05)$ terhadap konsumsi paka dan produksi telur ayam ras dan berpengaruh nyata $(\mathrm{P} \leq 0,05)$ terhadap bobot telur dan konversi pakan.

2. Kadar air dan lemak kasar telur ayam ras yang diberikan keong mas $0 \%, 5 \%, 10 \%$ dan $15 \%$ dalam ransum berpengaruh tidak nyata $(\mathrm{P}$ $\geq 0,05)$ dan berpengaruh nyata $(\mathrm{P} \leq$ $0,05)$ terhadap kadar protein kasar telur.

\section{DAFTAR PUSTAKA}

Amrullah, I.K. 2003. Nutrisi Aym Broiler.Seri Beternak Mandiri.

Badan Standar Nasional Indonesia, 2008. Standar Nasional Indonesia:3926: 2008. Telur Ayam Konsumsi.

Harris, L.E.1970. Nutrition Research Technique for Domestic and Wild Animal. vol.1, Animal Science Department Utah State Universty, Logan.Utah. 
Purnamaningsih, A. 2010. Pengaruh Pemberian Tepung Keong Mas Dalam Ransum Terhadap Kualitas Telur Itik. https: //www.pertanianku.com

Rahardjo, Y 2009. Kenali Penyebab Turunnya Produksi Telur. www.majalahinfovet.com/2a009/ 01/kenali-penyebab-turunnyaproduksi-te

Rasyaf, M. 1996. Manajemen Peternakan Ayam Petelur. Penebar Swadaya. Jakarta.

Saleh, M . 2016. Potensi Hama Keong Mas sebagai Pakan Itik Alabio. Penelitian Pertanian Lahan Rawa. Prosiding Seminar Nasional Inovasi Teknologi Pertanian. Banjarbaru.

Scott, M. 1., M. C. Nesheim and R. J. Young. 1984. Nutrition of the Chickens. Publ. M. L. ScottAssoc., Ithaca, N.Y

Subhan, A. 2014. Populasi dan Potensi Keong Mas (Pomacea canaliculata) Sebagai Sumber Bahan Pakan Itik Alabi (Anas Plathyrinchos Borneo). Balai Pengkajian Teknologi Pertanian Kalimantan Selatan, Indonesia Banjar baru Kalimantan Selatan.

Subhan, A. 2016. Pemanfaatan Keong Mas (Pomacea Canaliculata) Sebagai Sumber Asam Lemak Pakan Untuk Menurunkan Kadar Kolesterol Daging Dan Telur Itik Alabio (Anas Platyrhynchos Borneo) Yang Dipelihara Secara Intensif. Disertasi. Penerbit Yogyakarta Jakarta : Universitas Gajah Mada.
Sudarmono, A.S. 2003. Pedoman Pemeliharaan Ayam Ras Petelur. Penebar Swadaya. Jakarta.

Sulistiono, 2007. Keong Mas Sebagai Nutrisi Alami Alternatif. Fakultas Perikanan dan Ilmu Kelautan Institute Pertanian Bogor.

Surdayani,T dan Santoso. 1995. Pembibitan Ayam Ras. Penebar Swadaya. Jakarta.

Wahyu. J. 1996. Ilmu Nutrisi Unggas. Gajah Mada University Press.Yogyakarta.

Yuwanta, 2010. Dasar Ternak Unggas. Kanisius, Yogyakarta. 